\title{
Effect of Pre Harvest Spraying of Nutrients and Bagging with Different Colours of Polythene on Physico-Chemical Quality of Rainy Season Guava (Psidium guajava L.) Fruits cv. L-49
}

\author{
Krishna Kumar Mishra ${ }^{1 *}$, Sanjay Pathak ${ }^{1}$ and Mahendra Chaudhary ${ }^{2}$ \\ ${ }^{1}$ Department of Horticulture, N. D. U.A. \& T., Kumarganj, Faizabad-224229, U.P., India \\ ${ }^{2}$ Department of Horticulture C.S.A.U.A. \& T. Kanpur, U.P., India \\ *Corresponding author
}

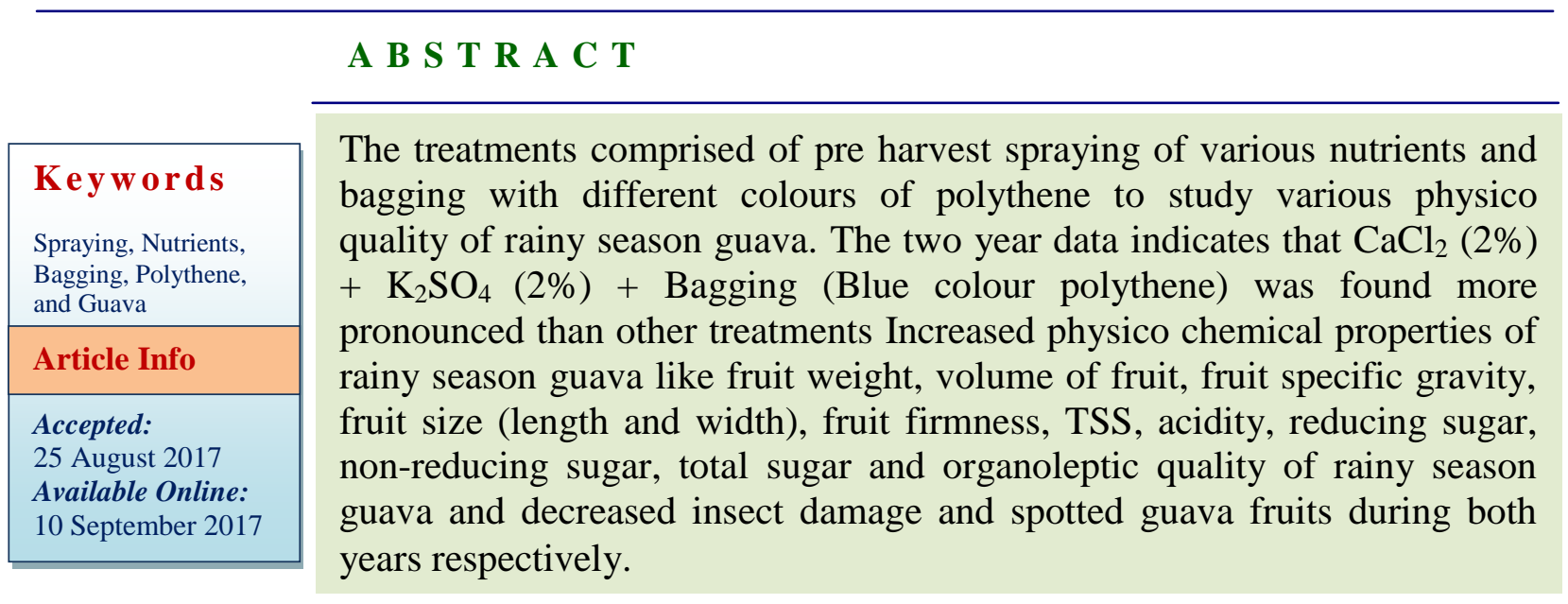

\section{Introduction}

Guava belongs (Psidium guajava L.) to the family Myrtaceae. Guava is a popular fruit widely grown in the tropical and subtropical regions of the world. The fruit originated in tropical America, stretching from Mexico to Peru gradually getting distributed to several countries of the world, where it got domesticated due to its excellent adaptability to different climatic conditions, hardy nature, prolific bearing. It is one of the important fruits of India and it is considered to be the poor man's apple. It has adopted in India so well that it appears to be an Indian fruit. Guava is considered as one of the exquisite, nutritionally valuable and remunerative crops.
It can be grown well in tropical and subtropical region. The importance of guava is due to the fact that it is a hardy fruit which can be grown in poor alkaline or poorly drained soils with minimum manuring and irrigation. It can be grown in soil with the $\mathrm{pH}$ ranging from 4.5 to 8.2. Guava is rich source of Vitamin-C and a fair source of Vitamin-A, Calcium, Phosphorus, Pantothenic acid, Riboflavin, Thiamin and Niacin. It is rich source of Pectin, hence suitable for Jelly making. Year round production is also a great factor which cannot be achieved due to removal of one season crop. This is only possible by means of development of 
technology for quality production of rainy season guava. Potassium regulates the opening and closing of stomata, the pores through which leaves exchange $\mathrm{CO}_{2}$, water vapor, and $\mathrm{O}_{2}$ with the atmosphere. The activation of enzymes by $\mathrm{K}$ and its involvement in adenosine triphosphate (ATP) production is probably more important in regulating the rate of photosynthesis than is the role of $\mathrm{K}$ in stomatal activity. Also the funtion of $\mathrm{K}$ transport of sugar, water and nutrient transport, protein synthesis, starch synthesis and crop quality.Pre harvest spraying of calcium directly on the fruit as a means of improving $\mathrm{Ca}$ uptake was adop ted. However, pre harvest spraying was found to improve firmness and shelf life of the fruits. Fruit enhance the level of $\mathrm{Ca}$ due to pre harvest treatment with $\mathrm{Ca}$ were found to have a greater resistence to the development of decay. Calcium effect on decay could be due to the formation of cell wall components resistent to degredation by pathogens.

\section{Materials and Methods}

The present investigation entitled "Effect of pre harvest spraying of nutrients and bagging with different colours of polythene physic chemical quality of rainy season guava (Psidium guajava L.) cv. Lucknow-49" was carried out on the orchard of guava at main experimental station of Horticulture and PostHarvest Technology laboratory, Narendra Deva university of Agriculture \& Technology, Kumarganj, Faizabad (U.P.) during two consecutive seasons 2015-16 \& 2016-17. Six years old bearing guava trees cv. Lucknow-49, having uniform vigour and healthy plants selected in guava orchard. The treatments combination $\mathrm{T}_{1}$ Control, $\mathrm{T}_{2} \mathrm{CaCl}_{2}$ (2\%), $\mathrm{T}_{3} \mathrm{~K}_{2} \mathrm{SO}_{4}(2 \%), \mathrm{T}_{4} \mathrm{CaCl}_{2}(2 \%)+\mathrm{K}_{2} \mathrm{SO}_{4}$ (2\%), $\mathrm{T}_{5} \mathrm{CaCl}_{2} @ 2 \%+$ Bagging (Red colour polythene), $\mathrm{T}_{6} \mathrm{CaCl}_{2} @ 2 \%+$ Bagging (Green colour polythene), $\mathrm{T}_{7} \mathrm{CaCl}_{2} @ 2 \%+$ Bagging (Yellow colour polythene), $\mathrm{T}_{8} \mathrm{CaCl}_{2} @ 2 \%+$
Bagging (Blue colour polythene), $\mathrm{T}_{9} \mathrm{~K}_{2} \mathrm{SO}_{4} @$ $2 \%+$ Bagging (Red colour polythene), $\mathrm{T}_{10}$ $\mathrm{K}_{2} \mathrm{SO}_{4} @ 2 \%+$ Bagging (Green colour polythene), $\mathrm{T}_{11} \mathrm{~K}_{2} \mathrm{SO}_{4} @ 2 \%+$ Bagging (Yellow colour polythene), $\mathrm{T}_{12} \mathrm{~K}_{2} \mathrm{SO}_{4} @ 2 \%+$ Bagging (Blue colour polythene), $\mathrm{T}_{13} \mathrm{CaCl}_{2}$ $(2 \%)+\mathrm{K}_{2} \mathrm{SO}_{4}(2 \%)+$ Bagging (Red colour polythene), $\mathrm{T}_{14} \mathrm{CaCl}_{2}(2 \%)+\mathrm{K}_{2} \mathrm{SO}_{4}(2 \%)+$ Bagging (Green colour polythene), $\mathrm{T}_{15} \mathrm{CaCl}_{2}$ $(2 \%)+\mathrm{K}_{2} \mathrm{SO}_{4}(2 \%)+$ Bagging (Yellow colour polythene), $\mathrm{T}_{16} \mathrm{CaCl}_{2}(2 \%)+\mathrm{K}_{2} \mathrm{SO}_{4}$ $(2 \%)+$ Bagging (Blue colour polythene) The experiment was laid out in Randomized Block Design (RBD) with 3 replications and bagging with different colours polythene before thirty days of harvesting during July, 2015 \& 2016. After harvested fruits were kept for physico chemical study at Post Harvest Laboratory, NDUA\&T, Kumarganj, Faizabad. The experimental data reported in the manuscript were analyzed statistically applying Randomized Block Design by the using method of "analysis of variance" as described by Cochran and Cox (1970).

\section{Results and Discussion}

The data pertaining to the effect of different colours of bagging and spraying of nutrients on average fruit weight, volume of fruits and specific gravity presented in Table 1. Out of all pre harvest treatments the maximum average fruit weight was recorded in treatment $\mathrm{T}_{15} \mathrm{CaCl}_{2}(2 \%)+\mathrm{K}_{2} \mathrm{SO}_{4}(2 \%)+$ Bagging (blue colour polythene) 167.44 and $158.77 \mathrm{~g}$ followed by 154.11 and $149.66 \mathrm{~g}$ in plants treated with $\mathrm{CaCl}_{2} @ 2 \%+$ Bagging (Red colour polythene) during both year respectively. The minimum fruit weight was noted in control i.e. 97.63 and $100.32 \mathrm{~g}$ during both years respectively. The appreciable improvement in fruit weight has been reported with application of $\mathrm{K}_{2} \mathrm{SO}_{4}$ by (Burondkar et al., 2002) and with $\mathrm{CaCl}_{2}$ by (Rubyrani and Brahamchari, 2004) in mango fruits. The maximum volume of fruit was 
recorded in treatment $\mathrm{K}_{2} \mathrm{SO}_{4} @ 2 \%+$ Bagging (Green colour polythene) 170.34 and 166.52 followed by 162.39 and $154.94 \mathrm{~cm}^{3}$ in $\mathrm{CaCl}_{2}(2 \%)+\mathrm{K}_{2} \mathrm{SO}_{4}(2 \%)+$ Bagging (Green colour polythene) during both year respectively. The minimum volume of fruit was recorded in control i.e. 99.89 and 102.56 $\mathrm{cm}^{3}$ during both years respectively. The above results were in close conformity with the findings of (Gulhane and Gupta, 1974) in guava. The maximum fruit specific gravity was recorded in treatment $\mathrm{K}_{2} \mathrm{SO}_{4} @ 2 \%+$ Bagging (Green colour polythene) 0.98 and the minimum fruit specific gravity was recorded during control 0.97 during both year respectively.

The above results are in accordance with the findings of Roy and Biswas, 1981 in Mango and Paralkar et al., 1987 in Sapota fruits. The data pertaining to the effect of different colours of bagging and spraying of nutrients on fruit firmness, insect damage and spotted fruits of rainy season guava fruits presented in Table 2. The fruits from plants treated with $\mathrm{CaCl}_{2}(2 \%)+\mathrm{K}_{2} \mathrm{SO}_{4}(2 \%)+$ Bagging (Blue colour polythene) were the most firm with firmness value of 10.67 and $9.71 \mathrm{~kg} / \mathrm{cm}^{2}$ followed by the pre harvest treatment of $\mathrm{CaCl}_{2}(2 \%)+\mathrm{K}_{2} \mathrm{SO}_{4}(2 \%)+$ Bagging (Green colour polythene) with firmness value of 10.13 and $9.23 \mathrm{~kg} / \mathrm{cm}^{2}$ during both year respectively. The lowest firmness value of 8.57 and $7.81 \mathrm{~kg} / \mathrm{cm}^{2}$ was recorded in control during both year respectively. Softening of fruits is caused by either by breakdown of insoluble proto-pectin into soluble pectin or cellular disintegration leading to membrane permeability (Mattoo et al., 1975). Pantastico et al., (1984) studied on 'Carabao' mango and reported that the fruit firmness decreased abruptly early in the ripening period. The maximum insect damage fruit were recorded in control and minimum was recorded in $\mathrm{CaCl}_{2}(2 \%)+\mathrm{K}_{2} \mathrm{SO}_{4}(2 \%)+$ Bagging (Blue colour polythene) during both year whereas other treatments showed significantly less infestation than control during both years respectively. Edirimanna et al., (2015) reported that colour and materials of bagging have significant effect on size and quality of the guava fruits. White and blue polythene bags are the most protecting for fruit fly attack. Abbasi et al., (2014) reported that Polythene bags reduced the damage by fruit fly to maximum extent followed by newspaper and muslin cloth bags on guava fruits. Minimum spotted fruits were found in plants treated with $\mathrm{CaCl}_{2}(2 \%)+\mathrm{K}_{2} \mathrm{SO}_{4}(2 \%)$ + Bagging (Blue colour polythene) and maximum spotted fruits were found in control during both years. The result corroborates with the findings of Garg et al., 2009 and Sindhu et al., (2009) revealed that the wax coating of pear fruits cv. Punjab beauty minimized the spoilage with excellent appearance and better fruit quality.

The data pertaining to the effect of different colours of bagging and spraying of nutrients on Total Soluble Solids, Acidity and Ascorbic acid of rainy season guava fruits presented in Table-3 data that all the pre harvest treatments and bagging with different colours of polythene influenced TSS content in guava fruits significantly. The maximum TSS content 15.00 and $13.00 \%$ was recorded both year in fruits treated with treatments $\mathrm{CaCl}_{2}$ $(2 \%)+\mathrm{K}_{2} \mathrm{SO}_{4}(2 \%)+$ Bagging (Blue colour polythene) the minimum TSS content of 7.06 and $4.50 \%$ was noted in control during both years respectively. The above results were in close conformity with the findings of Nanyakkara et al., (2005) and Wali and Kumar (2006) in mango fruits. The maximum acidity content of 0.67 and $0.69 \%$ was recorded in Control during both year respectively, while the minimum acidity content of 0.55 and 0.56 was recorded in $\mathrm{CaCl}_{2}(2 \%)+\mathrm{K}_{2} \mathrm{SO}_{4}(2 \%)+$ Bagging (Blue colour polythene) during both year respectively. 
Table.1 Effect of different colours bagging and spraying of nutrients on average fruit weight $(\mathrm{g})$, Volume of fruits $\left(\mathrm{cm}^{3}\right)$ and specific gravity of rainy season guava fruits

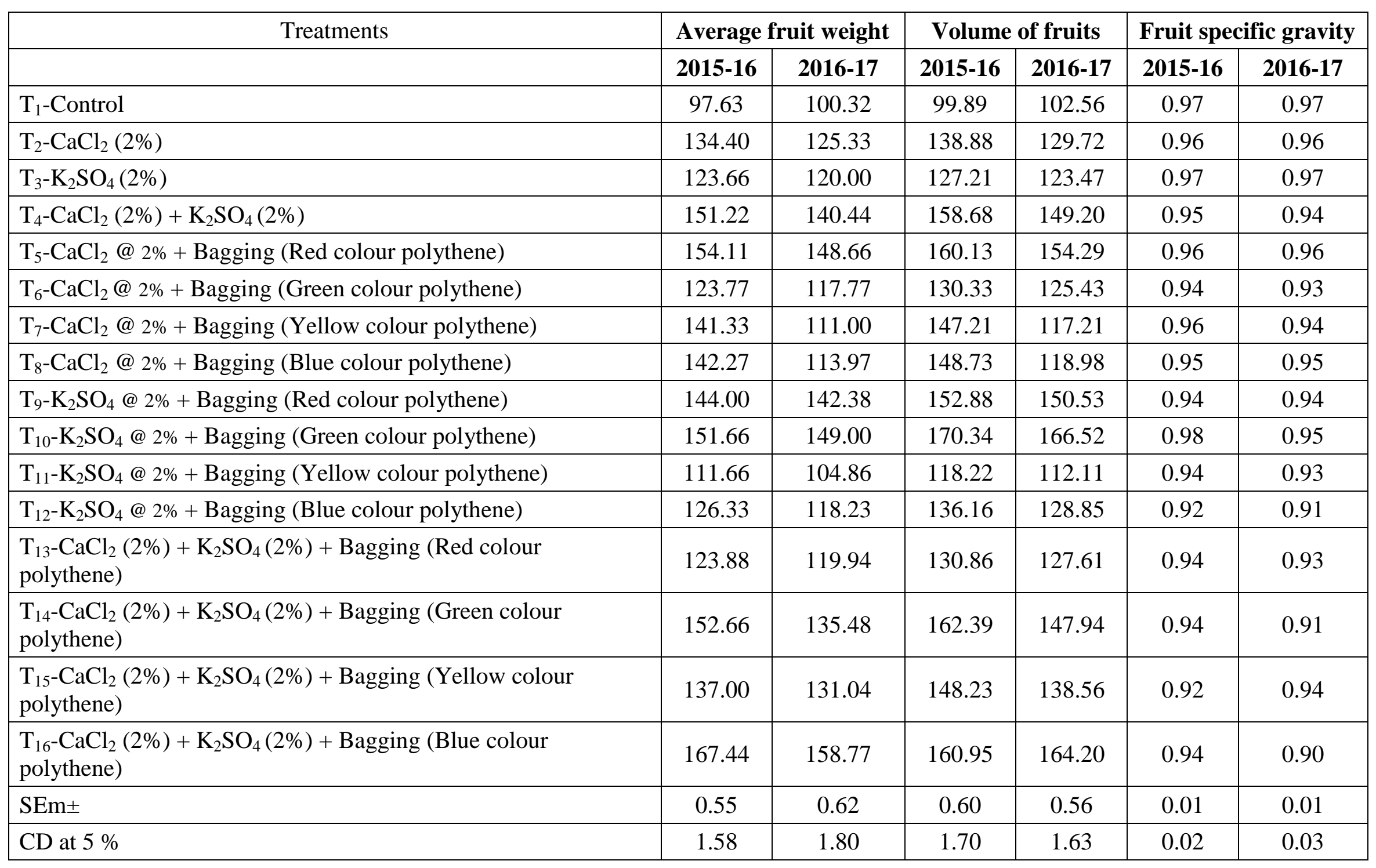


Table.2 Effect of different colours bagging and spraying of nutrients on Fruit firmness $\left(\mathrm{Kg} / \mathrm{cm}^{2}\right)$, Insect damage fruits and Spotted fruits $(\%)$ of rainy season guava fruits

\begin{tabular}{|c|c|c|c|c|c|c|}
\hline \multirow[t]{2}{*}{ Treatments } & \multicolumn{2}{|c|}{ Fruit firmness } & \multicolumn{2}{|c|}{ Insect damage fruits $(\%)$} & \multicolumn{2}{|c|}{ Spotted fruits } \\
\hline & $\begin{array}{c}2015- \\
16\end{array}$ & $\begin{array}{c}\text { 2016- } \\
17\end{array}$ & 2015-16 & 2016-17 & $\begin{array}{c}2015- \\
16\end{array}$ & $\begin{array}{c}2016- \\
17\end{array}$ \\
\hline $\mathrm{T}_{2}-\mathrm{CaCl}_{2}(2 \%)$ & 9.14 & 8.71 & 18.22 & 20.00 & 23.55 & 24.88 \\
\hline $\mathrm{T}_{3}-\mathrm{K}_{2} \mathrm{SO}_{4}(2 \%)$ & 9.18 & 8.91 & 17.34 & 17.56 & 25.44 & 26.88 \\
\hline $\mathrm{T}_{6}-\mathrm{CaCl}_{2} @ 2 \%+$ Bagging (Green colour polythene) & 9.46 & 8.41 & 0.10 & 0.13 & 0.72 & 0.98 \\
\hline $\mathrm{T}_{7}-\mathrm{CaCl}_{2} @ 2 \%+$ Bagging (Yellow colour polythene) & 9.44 & 8.44 & 0.03 & 0.10 & 0.81 & 1.09 \\
\hline $\mathrm{T}_{8}-\mathrm{CaCl}_{2} @ 2 \%+$ Bagging (Blue colour polythene) & 9.40 & 8.50 & 0.10 & 0.09 & 0.91 & 0.89 \\
\hline $\mathrm{T}_{9}-\mathrm{K}_{2} \mathrm{SO}_{4} @ 2 \%+$ Bagging (Red colour polythene) & 9.56 & 8.51 & 0.02 & 0.91 & 1.00 & 0.81 \\
\hline $\mathrm{T}_{13}-\mathrm{CaCl}_{2}(2 \%)+\mathrm{K}_{2} \mathrm{SO}_{4}(2 \%)+$ Bagging (Red colour polythene) & 9.90 & 8.89 & 0.33 & 0.77 & 0.92 & 0.98 \\
\hline $\begin{array}{l}\mathrm{T}_{14}-\mathrm{CaCl}_{2}(2 \%)+\mathrm{K}_{2} \mathrm{SO}_{4}(2 \%)+\text { Bagging (Green colour } \\
\text { polythene) }\end{array}$ & 10.11 & 9.23 & 0.44 & 0.74 & 0.88 & 0.84 \\
\hline $\begin{array}{l}\mathrm{T}_{15}-\mathrm{CaCl}_{2}(2 \%)+\mathrm{K}_{2} \mathrm{SO}_{4}(2 \%)+\text { Bagging (Yellow colour } \\
\text { polythene) }\end{array}$ & 9.80 & 9.21 & 0.54 & 0.57 & 0.78 & 0.21 \\
\hline $\begin{array}{l}\mathrm{T}_{16}-\mathrm{CaCl}_{2}(2 \%)+\mathrm{K}_{2} \mathrm{SO}_{4}(2 \%)+\text { Bagging (Blue colour } \\
\text { polythene) }\end{array}$ & 10.67 & 9.71 & 0.6 & 0.09 & 0.22 & 0.55 \\
\hline SEm \pm & 0.20 & 0.19 & 0.016 & 0.013 & 0.026 & 0.016 \\
\hline $\mathrm{CD}$ at $5 \%$ & 0.59 & 0.54 & 0.047 & 0.038 & 0.075 & 0.046 \\
\hline
\end{tabular}


Table.3 Effect of different colours bagging and spraying of nutrients on TSS (\%), acidity and ascorbic acid (mg/100g) of rainy season guava fruits

\begin{tabular}{|c|c|c|c|c|c|c|}
\hline \multirow[t]{2}{*}{ Treatments } & \multicolumn{2}{|c|}{ TSS } & \multicolumn{2}{|c|}{ Acidity } & \multicolumn{2}{|c|}{ Ascorbic acid } \\
\hline & 2015-16 & 2016-17 & 2015-16 & 2016-17 & 2015-16 & 2016-17 \\
\hline $\mathrm{T}_{1}$-Control & 7.06 & 4.40 & 0.67 & 0.69 & 145.00 & 143.91 \\
\hline $\mathrm{T}_{2}-\mathrm{CaCl}_{2}(2 \%)$ & 9.46 & 8.33 & 0.54 & 0.53 & 153.44 & 152.84 \\
\hline $\mathrm{T}_{3}-\mathrm{K}_{2} \mathrm{SO}_{4}(2 \%)$ & 9.46 & 9.33 & 0.56 & 0.55 & 156.81 & 156.00 \\
\hline $\mathrm{T}_{4}-\mathrm{CaCl}_{2}(2 \%)+\mathrm{K}_{2} \mathrm{SO}_{4}(2 \%)$ & 9.51 & 10.33 & 0.55 & 0.54 & 160.71 & 157.10 \\
\hline $\mathrm{T}_{5}-\mathrm{CaCl}_{2} @ 2 \%+$ Bagging (Red colour polythene) & 10.10 & 9.04 & 0.54 & 0.52 & 161.44 & 155.39 \\
\hline $\mathrm{T}_{6}-\mathrm{CaCl}_{2} @ 2 \%+$ Bagging (Green colour polythene) & 10.46 & 10.40 & 0.61 & 0.58 & 153.41 & 151.89 \\
\hline $\mathrm{T}_{7}-\mathrm{CaCl}_{2} @ 2 \%+$ Bagging (Yellow colour polythene) & 11.40 & 10.04 & 0.56 & 0.53 & 156.46 & 151.14 \\
\hline $\mathrm{T}_{8}-\mathrm{CaCl}_{2} @ 2 \%+$ Bagging (Blue colour polythene) & 13.23 & 12.13 & 0.58 & 0.56 & 177.00 & 175.00 \\
\hline $\mathrm{T}_{9}-\mathrm{K}_{2} \mathrm{SO}_{4} @ 2 \%+$ Bagging (Red colour polythene) & 13.50 & 11.20 & 0.51 & 0.55 & 159.61 & 150.21 \\
\hline $\mathrm{T}_{10}-\mathrm{K}_{2} \mathrm{SO}_{4} @ 2 \%+$ Bagging (Green colour polythene) & 11.40 & 10.33 & 0.56 & 0.54 & 155.21 & 149.40 \\
\hline $\mathrm{T}_{11}-\mathrm{K}_{2} \mathrm{SO}_{4} @ 2 \%+$ Bagging (Yellow colour polythene) & 10.06 & 9.43 & 0.63 & 0.60 & 164.30 & 157.43 \\
\hline $\mathrm{T}_{12}-\mathrm{K}_{2} \mathrm{SO}_{4} @ 2 \%+$ Bagging (Blue colour polythene) & 12.33 & 11.30 & 0.62 & 0.58 & 183.23 & 182.00 \\
\hline $\mathrm{T}_{13}-\mathrm{CaCl}_{2}(2 \%)+\mathrm{K}_{2} \mathrm{SO}_{4}(2 \%)+$ Bagging (Red colour polythene) & 9.98 & 9.23 & 0.60 & 0.57 & 169.31 & 167.00 \\
\hline $\begin{array}{l}\mathrm{T}_{14}-\mathrm{CaCl}_{2}(2 \%)+\mathrm{K}_{2} \mathrm{SO}_{4}(2 \%)+\text { Bagging (Green colour } \\
\text { polythene) }\end{array}$ & 11.05 & 10.33 & 0.58 & 0.57 & 171.00 & 172.06 \\
\hline $\begin{array}{l}\mathrm{T}_{15}-\mathrm{CaCl}_{2}(2 \%)+\mathrm{K}_{2} \mathrm{SO}_{4}(2 \%)+\text { Bagging (Yellow colour } \\
\text { polythene) }\end{array}$ & 10.46 & 9.36 & 0.56 & 0.54 & 167.40 & 161.10 \\
\hline $\mathrm{T}_{16}-\mathrm{CaCl}_{2}(2 \%)+\mathrm{K}_{2} \mathrm{SO}_{4}(2 \%)+$ Bagging (Blue colour polythene) & 15.00 & 13.00 & 0.54 & 0.55 & 194.00 & 192.00 \\
\hline SEm \pm & 0.26 & 0.25 & 0.01 & 0.01 & 0.45 & 0.58 \\
\hline CD at $5 \%$ & 0.76 & 0.72 & 0.04 & 0.03 & 1.35 & 1.66 \\
\hline
\end{tabular}


Table.4 Effect of different colours bagging and spraying of nutrients on Reducing sugars, Non-reducing sugars and Total sugars (\%) of rainy season guava fruits

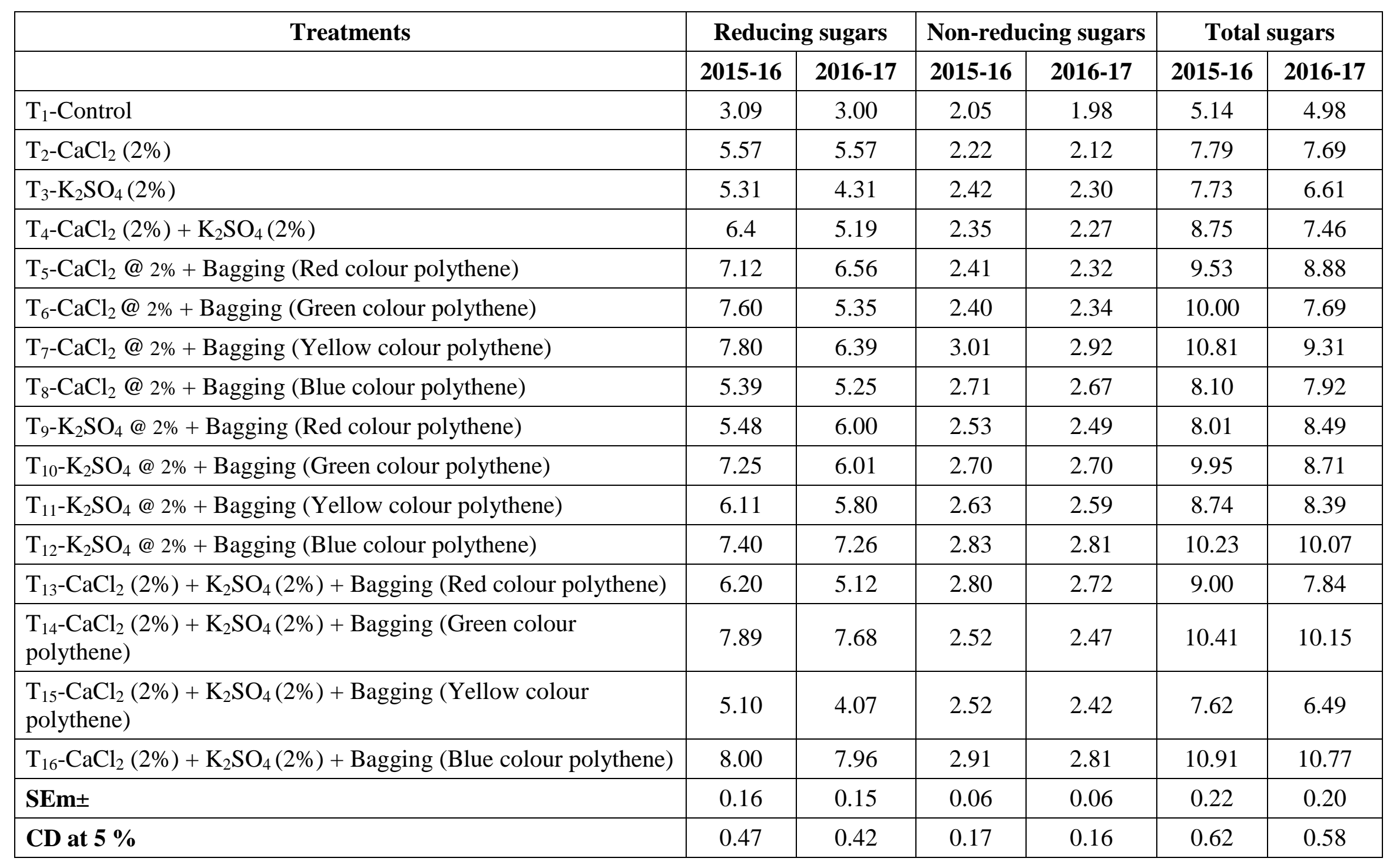


Table.5 Effect of different colours bagging and spraying of nutrients on organoleptic quality of rainy season guava fruits

\begin{tabular}{|c|c|c|c|c|}
\hline Treatments & Rating & Organoleptic quality & Rating & Organoleptic quality \\
\hline & $2015-16$ & 2015-16 & 2016-17 & 2016-17 \\
\hline $\mathrm{T}_{1}$-Control & 5.46 & $\begin{array}{l}\text { Neither like nor } \\
\text { dislike }\end{array}$ & 5.40 & $\begin{array}{l}\text { Neither like nor } \\
\text { dislike }\end{array}$ \\
\hline $\mathrm{T}_{2}-\mathrm{CaCl}_{2}(2 \%)$ & 6.42 & Like slightly & 6.20 & Like slightly \\
\hline $\mathrm{T}_{3}-\mathrm{K}_{2} \mathrm{SO}_{4}(2 \%)$ & 6.88 & Like slightly & 6.14 & Like slightly \\
\hline $\mathrm{T}_{4}-\mathrm{CaCl}_{2}(2 \%)+\mathrm{K}_{2} \mathrm{SO}_{4}(2 \%)$ & 7.93 & Like moderately & 7.89 & Like moderately \\
\hline $\mathrm{T}_{6}-\mathrm{CaCl}_{2} @ 2 \%+$ Bagging (Green colour polythene) & 7.78 & Like moderately & 7.75 & Like moderately \\
\hline $\mathrm{T}_{7}-\mathrm{CaCl}_{2} @ 2 \%+$ Bagging (Yellow colour polythene) & 7.60 & Like moderately & 7.58 & Like moderately \\
\hline $\mathrm{T}_{8}-\mathrm{CaCl}_{2} @ 2 \%+$ Bagging (Blue colour polythene) & 6.98 & Like slightly & 6.78 & Like slightly \\
\hline $\mathrm{T}_{9}-\mathrm{K}_{2} \mathrm{SO}_{4} @ 2 \%+$ Bagging (Red colour polythene) & 7.90 & Like moderately & 7.88 & Like moderately \\
\hline $\begin{array}{l}\mathrm{T}_{13}-\mathrm{CaCl}_{2}(2 \%)+\mathrm{K}_{2} \mathrm{SO}_{4}(2 \%)+\text { Bagging (Red colour } \\
\text { polythene) }\end{array}$ & 8.14 & Like very much & 8.04 & Like very much \\
\hline $\begin{array}{l}\mathrm{T}_{14}-\mathrm{CaCl}_{2}(2 \%)+\mathrm{K}_{2} \mathrm{SO}_{4}(2 \%)+\text { Bagging (Green colour } \\
\text { polythene) }\end{array}$ & 8.15 & Like very much & 8.04 & Like very much \\
\hline $\begin{array}{l}\mathrm{T}_{15}-\mathrm{CaCl}_{2}(2 \%)+\mathrm{K}_{2} \mathrm{SO}_{4}(2 \%)+\text { Bagging (Yellow colour } \\
\text { polythene) }\end{array}$ & 7.98 & Like moderately & 7.79 & Like moderately \\
\hline $\begin{array}{l}\mathrm{T}_{16}-\mathrm{CaCl}_{2}(2 \%)+\mathrm{K}_{2} \mathrm{SO}_{4}(2 \%)+\text { Bagging (Blue colour } \\
\text { polythene) }\end{array}$ & 8.84 & Like very much & 8.78 & Like very much \\
\hline SEm \pm & 0.17 & & 0.17 & \\
\hline CD at $5 \%$ & 0.48 & & 0.48 & \\
\hline
\end{tabular}


Other pre harvest treatments showed higher acidity content compared $\mathrm{T}_{16} \mathrm{CaCl}_{2}(2 \%)+$ $\mathrm{K}_{2} \mathrm{SO}_{4}(2 \%)+$ Bagging (Blue colour polythene) during both year respectively. Similarly, decreasing trend in acidity content of mango fruits during the storage period has also been reported by (Deol, 1985; Upadhyay and Tripathi, 1985). All the pre harvest treatments and bagging with different colours of The maximum ascorbic acid content of 194.00 and $192.00 \mathrm{mg} / 100 \mathrm{~g}$ was recorded when the plants were treated with $\mathrm{CaCl}_{2}(2 \%)$ $+\mathrm{K}_{2} \mathrm{SO}_{4}(2 \%)+$ Bagging (Blue colour polythene) followed by the treatment $\mathrm{K}_{2} \mathrm{SO}_{4}$ @ 2\%+ Bagging (Blue colour polythene) with ascorbic acid content of 183.13 and $182.00 \mathrm{mg} / 100 \mathrm{~g}$ during both year respectively. The minimum ascorbic acid content 145.00 and $143.91 \mathrm{mg} / 100 \mathrm{~g}$ was recorded in control during both years respectively. The above results are very close to the findings of Sharma et al., (1990) in mango, Singh et al., (2002) in ber, Dutta (2004) in guava and Gupta (2010) in aonla fruits. The data pertaining to the effect of different colours of bagging and spraying of nutrients on total sugars, reducing sugar and non-reducing sugar per cent of rainy season guava fruits presented in Table 4 data that all the treatments improved total sugars per cent in fruits. The treatments $\mathrm{CaCl}_{2}(2 \%)+\mathrm{K}_{2} \mathrm{SO}_{4}$ $(2 \%)+$ Bagging (Blue colour polythene) recorded maximum toatal sugars per cent 10.91 and $10.77 \%$ and the treatment $\mathrm{CaCl}_{2}$ $(2 \%)+\mathrm{K}_{2} \mathrm{SO}_{4}(2 \%)+$ Bagging (Green colour polythene) with total sugars content 10.81 and $10.15 \%$ remained at par with it during both year. The minimum total sugars content of 5.14 and 4.98 was recorded in control during both years respectively. The above results corroborate the findings of in mango, (Wali and Kumar, 2006) in guava and Gupta (2010) in aonla fruits. It is found that all the pre harvest treatments improved reducing sugars content in fruits significantly during both years. The treatments $\mathrm{CaCl}_{2}(2 \%)+\mathrm{K}_{2} \mathrm{SO}_{4}$
$(2 \%)+$ Bagging (Blue colour polythene) recorded the highest reducing sugars content of 8.00 and $7.96 \%$ and the pre harvest treatment with $\mathrm{CaCl}_{2}(2 \%)+\mathrm{K}_{2} \mathrm{SO}_{4}(2 \%)+$ Bagging (Green colour polythene)with reducing sugars content of 7.89 and $7.68 \%$ remained at par with it during both year. The minimum reducing sugars content of 3.09 and 3.00 was obtained on control during both years respectively. The pre harvest spray of calcium chloride have also been reported to improve the reducing sugars content of fruits by (Wali and Kumar, 2006; Goswami et al., 2008) in guava, and Gupta (2010) in aonla fruits. It is evident from the data that all the treatments improved non- reducing sugar content in fruits. The pre harvest treatments and different colours polythene bagging with $\mathrm{CaCl}_{2} @ 2 \%+$ Bagging (Yellow colour polythene) recorded the maximum nonreducing sugar content (3.01 and $2.92 \%$ ) and the pre harvest treatments and different colours bagging with $\mathrm{CaCl}_{2}(2 \%)+\mathrm{K}_{2} \mathrm{SO}_{4}$ $(2 \%)+$ Bagging (Blue colour polythene) with non-reducing sugar content of 2.91 and 2.81 remained at par with it during both year respectively. The minimum non-reducing sugar content was recorded in control during both years respectively. Similarly, the pre harvest spray of calcium chloride have also been reported to improve the non-reducing sugars content of fruits (Wali and Kumar, 2006; Goswami et al., 2008) in guava fruits and Gupta (2010) in aonla fruits. The data pertaining to the effect of pre harvest treatments and bagging with different colours of polythene on Organoleptic quality of rainy season guava fruits cv. Lucknow-49 is presented in Table 5. An introspection of revealed that all the pre harvest treatments improved Organoleptic quality of rainy season guava fruits. The treatments $\mathrm{CaCl}_{2}$ $(2 \%)+\mathrm{K}_{2} \mathrm{SO}_{4}(2 \%)+$ Bagging (Blue colour polythene) recorded the maximum Organoleptic quality of 8.84 and 8.78 (Like very much) during both years of experiment. 
Organoleptic quality of $\mathrm{CaCl}_{2}(2 \%)+\mathrm{K}_{2} \mathrm{SO}_{4}$ $(2 \%)+$ Bagging (Green colour polythene) 8.15 and 8.04 (Like very much) remained at par with it during both years respectively. The minimum Organoleptic quality of 5.46 and 5.40 (Neither like nor dislike) was obtained in control during both years respectively. Similarly, earlier workers have also reported that the fruit bagging can improves fruit quality mainly by keeping fruit appearance and preferable uniform coloration of the fruit as reported in apples (Wang et al., 2000), and grape (Signes et al., 2007).

\section{References}

Abbasi,N.A.; Chaudhary,M.A; Ali, M.I ; Hussain Azhar and Ali Irfan (2014) On tree fruit bagging influences quality of guava harvested at different maturity stages during summer, International Journal of Agriculture and Biology, 16, (3) : 543-549.

Burondkar, M.M.; Jadhav, B.B. and Chetti, M.B. (2002). Effect of plant growth regulators, polyamine and nutrients on fruit quality and occurrence of spongy tissue in Alphonso mango. Acta Horticulture, 820: 243-248

Cockran, W.G. and Cox, G.M. (1970). Experimental design. First Indian Edition, 1950.

Deol, I.S. (1985). A study on chemical changes during the storage life of Sumar Bahist Chausa mango (Mangifera indica L.). Punjab Hort. J., 25(1-4): 511.

Dutta, P. 2004. Studies on foliar nutrition in guava. The Orissa J. Hort., 32(1):103104.

Edirimanna, E.R.S.P., Amarathunga, D.K., Amarasena, B.G and Kirinde, T. (2015). Effect of bagging materials and bag colour on fruit weight and quality of guava (Pisidum guajava L.). Annuals of Sri Lanka Deptt. of Agril. 17: 297-302.
Garg, N.; Singh, B.P. and Sarolia, D. (2009). Effect of herbal wax on ripening behavior and surface microbial load of mango. Journal of Eco-friendly Agri., 4(1): 85-57.

Goswami, A.K.; Sharma, R.M. and Kumar, R. (2008). Effect of pre and post-harvest treatment of calcium on quality and shelf life of guava fruit cv. Sardar. Acta Horticulture. 682: 1281-1286.

Gupta, R.C. (2010). Studies on shelf life of aonla (Emblica officinalis Geartn.) fruits. M.Sc. (Ag.) thesis, N.D.U.A. $\&$ T., Faizabad.

Matoo, A.K.; Murata, T.; Pantastico, E.B; Ogata, K. and Phan, C.T. (1975). Chemical changes during ripening and senescence. In: Pantastico (ed.) Postharvest physiology, Handling and Utilization of Tropical and Sub-tropical Fruits and Vegetables. AVI Pub. Co. Inc. p.103-127.

Nanyakkara, C.K.; Mustafa, M.M. and Sathiamurthy, S. (2005). Effect of the pre harvest spray of $\mathrm{K}_{2} \mathrm{SO}_{4}$ and ethephon on ripening and quality of mango fruits. Acta Horticulture, 509: 413-418.

Pantastico, E.B., Lam, P.F., Ketsa, S., Yuniarti and Kosittrakul, M., (1984). Postharvest physiology and storage of mango. In: Mango -fruit Development, Postharvest Physiology and Marketing in ASEAN. (Mendoza, D.B. Jr. and Wills, R.B.H. (eds)). Asian Food Handling Bureau, Kuala Lumpur, p. 4143.

Peter (1999). Bagging of mango (Mangifera indica cv. 'Kiett') fruit influences fruit quality and mineral composition. Postharvest Biol. Technol., 12: 83-91.

Rubyrani and brahamchari, V.S. (2004). Effect of growth substances and calcium compound on fruit retention, growth and yield of Amrapali mango. The Orissa J. of Hort., 32(1): 15-18. 
Signes, J.A.; Burlo, F.; Martinej, F. and Carbonel, A.A. (2007). Effect of preharvest bagging on quality of Black Table grapes. World J. of Agri. Sci., 3(1): 32-38.

Sindhu, G.S; Dhillon, W.S. and Mahajan, B.V.S. (2009). Effect of waxing and packaging on pear cv. Punjab Beauty. Indian J. Hort., 66(2): 239-244.

Singh, S.; Singh, A.K. and Bagel, B.G. (2002). Effect of folial application of nutrients and growth regulators on quality and storage life of ber fruits. The Orissa J. Hort., 36(1): 126-130.

Upadhyay, N.P. and Tripathi, B.M. (1985). Post-harvest changes during storage and ripening of Gaurjeet mango (Mangifera indica L.) fruits. Prog. Hort., 17(1): 2527.

Wali, V. K. and Kumar, Sermesh (2006). Effect of pre-harvest sprays of calcium, zinc and silver on physio-chemical characteristics of guava. (Psidium gaujava L.) cv. Sardar during storage. Journal of Research, SKUAST-J, 5 (1).

Wang, H.Q.; Arakawa, O. and Motomura, Y. (2000). Influence of maturity and bagging on the relationship between anthocyanin accumulation and phenylalanine ammonia-lyase (PAL) activity in 'Jonathan' apples. Postharvest Biol. Technol., 19: 123-128

\section{How to cite this article:}

Krishna Kumar Mishra, Sanjay Pathak and Mahendra Chaudhary. 2017. Effect of Pre Harvest Spraying of Nutrients and Bagging with Different Colours of Polythene on Physico-Chemical Quality of Rainy Season Guava (Psidium guajava L.) Fruits cv. L-49. Int.J.Curr.Microbiol.App.Sci. 6(9): 3797-3807. doi: https://doi.org/10.20546/ijcmas.2017.609.469 